\title{
Shallow geothermal energy in Denmark
}

\author{
Thomas Vangkilde-Pedersen, Claus Ditlefsen and Anker Lajer Højberg
}

The use of shallow geothermal energy instead of fossil fuels can lead to substantial reductions in $\mathrm{CO}_{2}$ emissions. However, the use of shallow geothermal energy in Denmark is limited compared to, e.g. Sweden and Germany and we still lack know-how and experience with its use in Denmark. In co-operation with research and industry partners, the Geological Survey of Denmark and Greenland is conducting a three-year project GeoEnergy, Tools for ground-source heating and cooling based on closed-loop boreholes (www.geoenergiorg). The objective of the project is to acquire knowledge and develop tools and best practice for the design and installation of shallow geothermal energy systems.

\section{Exploitation of shallow geothermal energy}

In the shallow subsurface, solar energy absorbed and stored in the ground determines the temperature, whereas the temperature gradient is determined by the heat flux from the interior of the Earth. In Denmark the net insolation is $c$. $400 \mathrm{kWh} / \mathrm{m}^{2} /$ year and in the upper few hundred metres, the heat flux from the interior is $c .0 .20$ to $0.35 \mathrm{kWh} / \mathrm{m}^{2} /$ year (Balling et al. 1992). The geothermal gradient in Denmark is $25-30^{\circ} \mathrm{C}$ per kilometre (Mathiesen et al. 2009) with an upper zone of seasonal variations. The thickness of this zone has not been investigated in detail in Denmark, but a general thickness of 10-20 m may be expected (Fig. 1; Banks 2008). The shallow geothermal energy is exploited in combination with heat pumps bringing the temperature to the desired operating temperature of the heating (or cooling) system. A ground-source heat pump, however, requires energy in the form of heat or cold from the ground as well as electricity for the operation of the pump itself.

The energy extraction from the ground can be based on either open-loop systems or closed-loop systems. In open-loop systems, groundwater from a production well is used directly as an energy source for the heat pump and returned to the aquifer via an injection well. The efficiency is high due to a constant and relatively high temperature of the water (typically $8-10^{\circ} \mathrm{C}$ ), but a suitable aquifer with sufficient yield is required and conflicts of interest with neighbouring installations or nearby drinking water catchment may arise. In closed-loop systems, water with antifreeze is circulated in the ground in high-density polyethylene pipes and acts as a heat exchanger. The heat capacity of soil and groundwater is relatively high, whereas the thermal conductivity is moderate and dependent on the local hydrogeology. Therefore the heat exchanger must be relatively large, i.e., the polyethylene pipes relatively long. They can either be installed horizontally at a depth of $c .1 \mathrm{~m}$ (horizontal closed-loop systems), or vertically in a borehole (borehole heat exchanger or vertical closed-loop system; Fig. 2).

Vertical systems are only influenced by seasonal temperature variations in the upper zone down to $10-20 \mathrm{~m}$ and have a higher efficiency than horizontal systems due to a higher and constant ground temperature. On the other hand, the temperature regime around a vertical system is only slowly re-generated and careful design with respect to the energy demand is necessary, and an accurate estimate of the energy consumption is needed to optimise the design of the system. Alternating operations with heating during winter and cooling during summer, supplemented with seasonal storage of

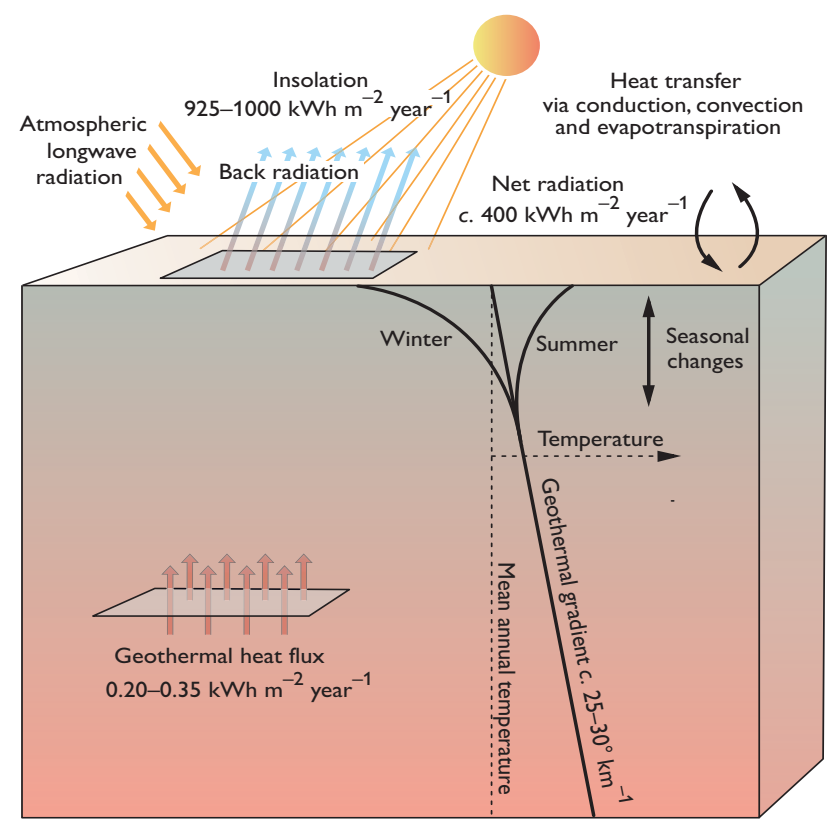

Fig. 1. Schematic block diagram showing the geothermal gradient and magnitude of geothermal heat flux and insolation with average values for Denmark as well as the seasonal zone of fluctuation in temperature (modified from Banks 2008). 
heat from, e.g. solar panels, can optimise the efficiency of vertical systems.

\section{Groundwater and environmental protection}

Protection of the environment and groundwater is of paramount importance in shallow geothermal projects. The main issues are leakage of water with antifreeze, cross-connecting different aquifers, seepage of surface water along the borehole, drilling into artesian aquifers and unwanted thermal effects. All steps in the production and installation of a ground loop must be designed for optimum tightness and longevity of the loop. Installation procedures must minimise the risk of damaging the pipes, and a pressure test of the pipes must be carried out. The legislation also specifies which antifreeze agents can be used in the ground loop - only non-toxic and easily biodegradable fluids are allowed.

Closed-loop boreholes must be sealed with low permeable grout in order to prevent contact between the surface and aquifers or between individual aquifers and the quality of the sealing determines the protection of the groundwater, as for all other boreholes. Grouting is also necessary to improve the heat transfer from the ground to the pipes and in actual practice the entire borehole is sealed with grout.

Perforation of an artesian aquifer can cause large quantities of water to press through the drill pipe disrupting the grout. To avoid drilling closed-loop boreholes into artesian aquifers, local hydraulic heads must be checked prior to drilling (Ditlefsen 2012).

Possible problems with thermal pollution for horizontal systems are described by Banks (2008). Extraction of heat may cause freezing of the ground and frost heaving, which can

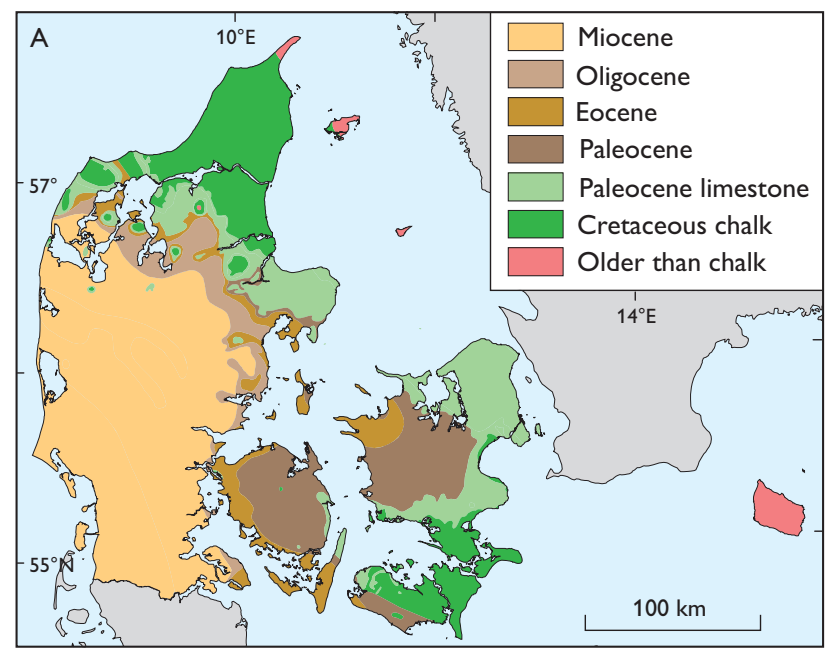

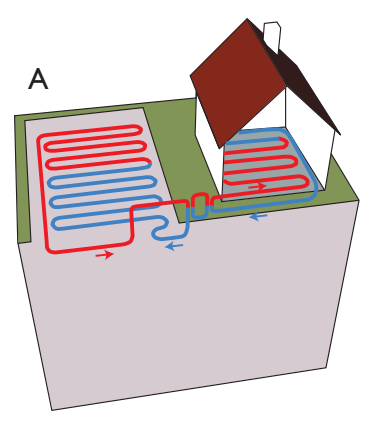

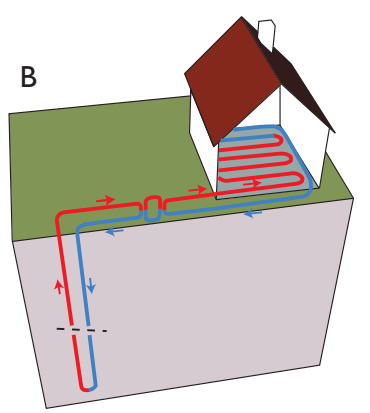

Fig. 2. Principles of horizontal (A) and vertical (B) closed-loop, groundsource heat-pump systems.

potentially damage surface structures, buried installations and plant roots. Warming of the ground may cause vapour migration and progressive drying and perhaps even shrinkage of soils. Significant heating of the ground can also lead to consolidation and settling in clayey, unconsolidated soils and thermal interference between neighbouring ground-source energy schemes may occur. In the Danish legislation for closed-loop systems safety distances to other ground heat exchangers and to extraction wells for drinking water are specified, but not to buildings and other structures. For open- loop systems the limitations in the allowable thermal influence on the groundwater are rather strict.

\section{Evaluation of thermal properties of Danish sediments}

In Denmark vertical systems are normally drilled to depths of 50-200 m. In order to evaluate the possible energy extraction from a specific new site and estimate the required depth and number of boreholes, information about the geology and hydrogeology is crucial. The greater part of Denmark is under-

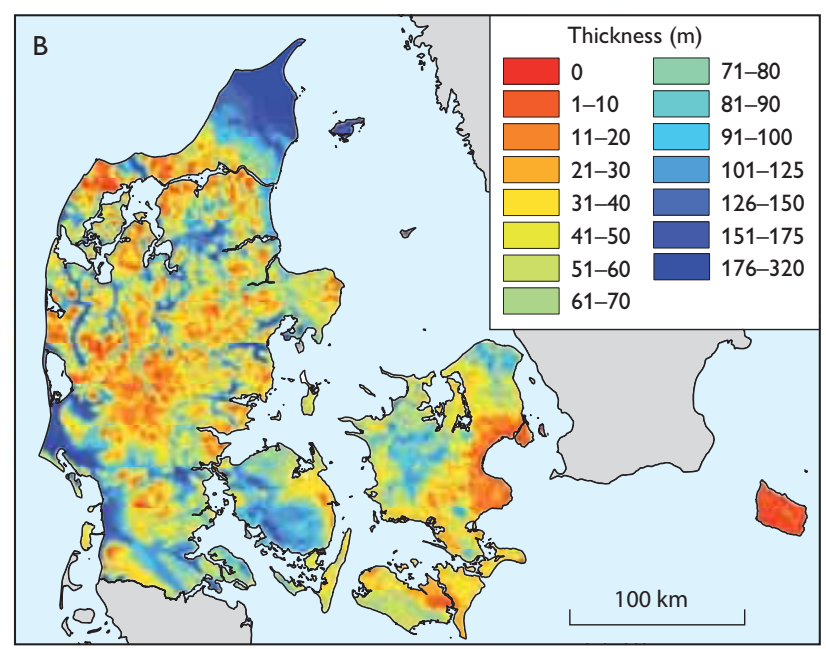

Fig. 3. Maps showing the pre-Quaternary geology (A) and the thickness of Quaternary sediments (B) in Denmark. 
Table 1.Thermal conductivity of different sediment and rock types

\begin{tabular}{|c|c|c|c|c|}
\hline \multirow[t]{2}{*}{ Sediment/rock } & \multirow{2}{*}{$\begin{array}{l}\text { Thermal conductivity } \\
\qquad \mathrm{W} \mathrm{mK} \mathrm{m}^{-1}\end{array}$} & \multirow{2}{*}{$\begin{array}{l}\text { Recommended values } \\
\qquad \mathrm{W} \mathrm{mK^{-1 }}\end{array}$} & \multicolumn{2}{|c|}{ Estimated specific heat extraction rate $\left(\mathrm{W} \mathrm{m}^{-1}\right)$} \\
\hline & & & VDI (2001) & MCS (2011) \\
\hline Clay and silt (dry) & $0.4-1.0 *$ & $0.5^{*}$ & - & - \\
\hline Water-saturated clay and silt & $1.1-3.1 *$ & $1.8^{*}$ & $35-50$ & $21-34$ \\
\hline Palaeogene clay, Denmark & $1.34-1.56 \dagger$ & - & - & - \\
\hline Sand (dry) & $0.3-0.9 *$ & $0.4^{*}$ & 25 & - \\
\hline Water-saturated sand & $2.0-3.0 *$ & $2.4^{*}$ & $65-80$ & $26-45$ \\
\hline Water-saturated gravel & $1.6-2.5^{*}$ & $1.8^{*}$ & - & - \\
\hline Till/loam & $1.1-2.9 *$ & $2.4^{*}$ & - & - \\
\hline Clayey till, Denmark & $2.00-2.31 \ddagger$ & - & - & - \\
\hline Chalk, England & $1.79 \pm 0.54 \S$ & - & - & - \\
\hline Chalk, Denmark & $1.45-1.86 \dagger$ & - & - & - \\
\hline Quartzite & $5.5-7.5 \S$ & $6.0 \S$ & - & - \\
\hline Granite & $3-4 \S$ & $3.4 \S$ & $65-85$ & $33-45$ \\
\hline
\end{tabular}

* VDI (2010). † Balling et al. (1981). ${ }^{\ddagger}$ Porsvig (1986). § Banks (2008).

lain by a sedimentary basin dominated by shallow marine to deep marine clastic and biogenic sediments (Fig. 3A), overlain by Quaternary deposits. In some areas the Quaternary cover is thin and limestone or Tertiary sand, silt and mud are found close to the surface. Thick successions of Quaternary sediments are common in the northern and south-western part of the country (Fig. 3B). In these areas the Quaternary sediments are dominated by marine and glaciomarine deposits. Thick successions of Quaternary deposits are also found in buried valleys (Jørgensen \& Sandersen 2006). The geological variation within the Quaternary sediments is high and regionalscale geological models are not sufficiently detailed to estimate the possible energy extraction from a vertical system. Local information from boreholes and geophysical data are necessary to map the Quaternary strata and the elevation of the water table.

The potential flow of energy in and out of a vertical system is determined by the heat capacity and the thermal conductivity of the sediments or rocks surrounding the borehole. The process is dominated by heat conduction, but advective transport in the groundwater also plays a role. The thermal conductivity of geological materials depends on the porosity, water content and mineral composition. Rocks and sediments with a high content of quartz have high thermal conductivity, whereas porous, unsaturated sediments have low thermal conductivity due to the presence of air in the pore space. Thermal conductivity values for different rock and sediment types are compiled in Table 1 and show large variations for saturated clay and silt as well as for till deposits, which are common sediments in Denmark. Most of the values are from Germany and the UK and to get more information about common Danish lithologies new measurements are required.

\section{Modelling of near-surface heat flow in a Danish context}

Various model systems are available for calculating the efficiency of vertical systems in terms of energy extraction, ranging from simple and easy-to-use models to complex numerical models. The easy-to-use models consider the longterm aspects assuming homogeneous and constant subsurface thermal properties, whereas the complex models also take into account the effect of alternating system operation, heterogeneity in thermal properties as well as groundwater flow. Assuming standard design and 1800 hours of production per year, specific heat extraction rates for selected sediment and rock types have been estimated for German (VDI 2001) and British (MCS 2011) conditions based on vertical systems with double- and single-loop pipes, respectively (Table 1). The values indicate large variations between different sediment types and within specific geological facies as well as between the German and British studies, stressing the importance of establishing valid standard values applicable for Danish conditions and different systems. The possible energy extraction for $100 \mathrm{~m}$ vertical, closed-loop boreholes has been calculated for four simple geological successions (Fig. 4). The estimated energy extraction for the most unfavourable of the geological scenarios $(7560 \mathrm{kWh})$ is only $c$. $60 \%$ of the energy extraction for the most favourable (12 537 $\mathrm{kWh}$ ), thus giving an indication of the possible effect of different geological settings.

In addition to heterogeneity in geology and thermal properties, the efficiency of vertical systems is affected by possible groundwater flow. If the system is operating only in heating or cooling mode, groundwater flow will have a positive impact on the efficiency due to the continuous supply of energy. On the other hand, groundwater flow will have a negative 


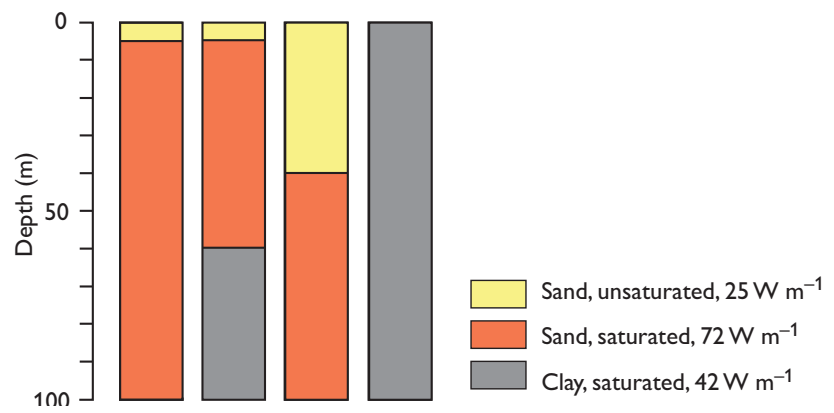

Fig. 4. Four simple geological successions with average, specific heat-extraction rates from Table 1 VDI (2001). The possible energy extraction has been calculated to $12537 ; 10373 ; 9576$ and $7560 \mathrm{kWh}$ (left to right), based on 1800 hours of production per year (borehole length $\times$ specific heat extraction rate $\times$ hours of production).

impact on systems using the subsurface for seasonal energy storage, because the flow will transport heat and cold away from the vertical system. To evaluate the importance of the hydrogeological heterogeneity observed in Denmark, modelling will be carried out based on a complex numerical model that allows the inclusion of subsurface heterogeneity as well as groundwater flow. The aim of the modelling is to identify the aspects that must be considered in the design phase of closed loop systems, and estimate the maximum energy that can be extracted under different hydrogeological conditions typical in Denmark.

\section{Perspectives for shallow geothermal energy in Denmark}

Shallow geothermal energy is a competitive, renewable energy resource as domestic heat pumps typically produce $3-4$ times the amount of energy they consume in the form of electricity. Depending on how the electricity is generated and taking the generation and transmission loss into consideration, heating a building using ground-source energy produces only half of the $\mathrm{CO}_{2}$ emission of fossil fuels used directly for heating (Banks 2008). Nevertheless, the application of shallow geothermal energy in Denmark is relatively limited. In 2008, the number of ground-source heat-pump installations was c. 25000 (Willumsen 2008), with the vast majority being horizontal systems. So far, only a few hundred of the installed systems are based on closed-loop boreholes, and the number of groundwater-based open-loop systems is limited to a few tens. Hopefully the GeoEnergy project can pave the way for a wider use of shallow geothermal energy, but in order to fully exploit the resource, a systematic assessment of the potential is needed, including the potential for seasonal storage of waste heat. With the continuous focus on climate change and energy consumption, the number of installations is likely to increase rapidly in the coming years, especially after a political decision has been made to phase out domestic oil burners starting in 2012. The manifold exploitation of various shallow geological resources, including shallow geothermal energy, drinking water and minerals, will increase the demand for resource management and data availability.

\section{Acknowledgement}

The EUDP programme of the Danish Energy Agency is thanked for financial support to the GeoEnergy project.

\section{References}

Balling, N., Kristiansen, J.I., Breiner, N., Poulsen, K.D., Rasmussen, R. \& Saxov, S. 1981: Geothermal measurements and subsurface temperature modelling in Denmark. GeoSkrifter 16, 176 pp.

Balling, N., Nielsen, S.B., Christiansen, H.S., Christensen, L.D. \& Poulsen, S. 1992: The subsurface thermal regime and temperature of geothermal reservoirs in Denmark. Synthesis report to the Commission of the European Communities, Contract EN3G-0029-DK, 91 pp. Århus: Department of Earth Sciences, University of Aarhus.

Banks, D. 2008: An introduction to thermogeology: ground source heating and cooling, $351 \mathrm{pp}$. Oxford: Blackwell.

Ditlefsen, C. 2012: D1 Geologi og jordvarmeboringer. Oversigt over geologiske forhold af betydning ved etablering af jordvarmeboringer. GeoEnergi - Energianlæg baseret på jordvarmeboringer - udvikling af markedsfremmende værktøjer og best practice. EUDP projekt, J.nr. 64011-0003.

Jørgensen, F. \& Sandersen, P.B.E. 2006: Buried and open tunnel valleys in Denmark - erosion beneath multiple ice sheets. Quaternary Science Reviews 25, 1339-1363.

Mathiesen, A., Kristensen, L., Bidstrup, T. \& Nielsen, L.H. 2009: Vurdering af det geotermiske potentiale i Danmark. Danmarks og Grønlands Geologiske Undersøgelse Rapport 2009/59, 30 pp.

MCS (Microgeneration Certification Scheme) 2011: Microgeneration installation standard: MIS 3005. Issue 3.0. London: Department of Energy and Climate Change.

Porsvig, M. 1986: Varmeovergangsforhold omkring jordslanger. Energiministeriets varmepumpeforskningsprogram $33,56 \mathrm{pp}$.

VDI (Verein Deutscher Ingenieure) 2001: Thermische Nutzung des Untergrundes: Erdgekoppelte Wärmepumpenanlagen. Richtlinie 4640, Blatt 2, 43 pp. Düsseldorf: Verein Deutscher Ingenieure.

VDI (Verein Deutscher Ingenieure) 2010: Thermische Nutzung des Untergrundes: Grundlagen, Genehmigungen, Umweltaspekte. Richtlinie 4640, Blatt 1, 33 pp. Düsseldorf: Verein Deutscher Ingenieure.

Willumsen, B. 2008: Jordvarmeanlæg. Teknologier og risiko for jord- og grundvandsforurening, 176 pp. Miljøprojekt nr. 1238. Copenhagen: Miljøstyrelsen.

\footnotetext{
Authors' address

Geological Survey of Denmark and Greenland, Lyseng Allé1, DK-8270 Højbjerg, Denmark. E-mail: tvp@geus.dk
} 